\title{
Germination and sporophytic development of Regnellidium diphyllum Lindman (Marsileaceae) in the presence of hexavalent chromium
}

\author{
Kieling-Rubio, $M A .^{\mathrm{a}, \mathrm{b}}$, Droste, $A .^{\mathrm{c} *}$ and Windisch, $P G .^{\mathrm{a}}$ \\ aPrograma de Pós-graduação em Botânica, Universidade Federal do Rio Grande do Sul - UFRGS, \\ Av. Bento Gonçalves, 9500, CEP 91501-970, Porto Alegre, RS, Brazil \\ 'Programa de Pós-graduação em Biologia, Universidade do Vale do Rio dos Sinos - Unisinos, \\ Av. Unisinos, 950, CEP 93022-000, São Leopoldo, RS, Brazil \\ 'Programa de Pós-graduação em Qualidade Ambiental, Universidade Feevale, Rod. RS-239, 2755 , \\ CEP 93352-000, Novo Hamburgo, RS, Brazil \\ *e-mail: annette@feevale.br \\ Received February 21, 2010 - Accepted April 29, 2010 - Distributed December 31, 2010
}

(With 1 figure)

\begin{abstract}
Regnellidium diphyllum Lindman is a heterosporous fern, growing in aquatic environments and surrounding wetlands, which is assumed to be threatened by increasing water pollution and disappearance of its natural habitats. Among contaminants, hexavalent chromium - $\mathrm{Cr}(\mathrm{VI})$ - is known to be present in effluents from some leather tanning factories. Megaspore germination tests were performed using Meyer's solution, at concentrations 0 (control), 0.1, 0.5, 1, 5, 10, 15, 20, 30, 50, and $80 \mathrm{mg} . \mathrm{L}^{-1}$, from a standard solution of Titrisol ${ }^{\circledR} 1000 \mathrm{mg}$. $\mathrm{L}^{-1}$. The primary development of apomictic sporophytes was studied using solutions containing 0.025 to $4.8 \mathrm{mg} . \mathrm{L}^{-1}$ of $\mathrm{Cr}(\mathrm{VI})$. The experiments were conducted in a growth chamber at $24 \pm 1{ }^{\circ} \mathrm{C}$ and for a 12-hour photoperiod under fluorescent lights, providing a nominal irradiance of $77 \mu \mathrm{mol} . \mathrm{m}^{-2} / \mathrm{s}$. Significant differences in megaspore germination, with subsequent sporophytic development, were verified from $0.5 \mathrm{mg} . \mathrm{L}^{-1} \mathrm{Cr}(\mathrm{VI})$ concentration onwards. Growth of primary root and primary and secondary leaves was significantly reduced at $3.2 \mathrm{mg} . \mathrm{L}^{-1} \mathrm{Cr}(\mathrm{VI})$ concentration or higher. Considering the pollution from $\mathrm{Cr}(\mathrm{VI})$ in some areas of $R$. diphyllum natural occurrence, these data indicate that low reproductive rates and disappearance of populations are likely to occur in these situations.
\end{abstract}

Keywords: heavy metals, ferns, aquatic macrophytes, pollution.

\section{Germinação e desenvolvimento esporofítico de Regnellidium diphyllum Lindman (Marsileaceae) na presença de cromo hexavalente}

\begin{abstract}
Resumo
Regnellidium diphyllum Lindman é uma filicínea heterosporada que se desenvolve em ambientes aquáticos e áreas úmidas circundantes, sendo considerada ameaçada pelo aumento da poluição e desaparecimento dos seus hábitats naturais. Entre os contaminantes, o cromo hexavalente - Cr(VI) - é conhecido por estar presente nos efluentes de algumas indústrias de curtimento de couro. Testes de germinação foram realizados em meio líquido de Meyer, com concentrações de 0 (controle); 0,$1 ; 0,5 ; 1 ; 5 ; 10 ; 15 ; 20 ; 30 ; 50 ;$ e 80 mg.L $\mathrm{L}^{-1}$ de $\mathrm{Cr}(\mathrm{VI})$, a partir de uma solução padrão de Titrisol ${ }^{\circledR}$ a 1000 mg.L $\mathrm{L}^{-1}$. O desenvolvimento primário dos esporófitos apomíticos foi analisado em meios contendo de 0,025 a 4,8 mg. $\mathrm{L}^{-1} \mathrm{de} \mathrm{Cr}(\mathrm{VI})$. Os experimentos foram conduzidos em câmara de crescimento a $24 \pm 1^{\circ} \mathrm{C}$, fotoperíodo de 12 horas com lâmpadas fluorescentes fornecendo irradiância nominal de $77 \mu \mathrm{mol} . \mathrm{m}^{-2} / \mathrm{s}$. Diferenças significativas na germinação dos megásporos e seu subsequente desenvolvimento foram verificadas a partir da concentração $0,5 \mathrm{mg} . \mathrm{L}^{-1}$ de $\mathrm{Cr}(\mathrm{VI})$. O crescimento da raiz primária e das folhas primárias e secundárias foi significativamente reduzido na concentração 3,2 mg. $\mathrm{L}^{-1}$ de $\mathrm{Cr}(\mathrm{VI})$ ou superior. Considerando a poluição proveniente por $\mathrm{Cr}(\mathrm{VI})$ em algumas áreas de ocorrência natural de $R$. diphyllum, esses dados indicam que as baixas taxas de reprodução e mesmo o desaparecimento das populações podem ser esperadas nessas situações.
\end{abstract}

Palavras-chave: metais pesados, filicínea, macrófitas aquáticas, poluição. 


\section{Introduction}

The intense use of products that contain heavy metals increases pollution levels in various ecosystems, causing adverse effects and altering patterns of natural biogeochemical cycles. Therefore, heavy metals have received special attention since they are not biodegraded or biotransformed, remaining as persistent contaminants in ecosystems and food chains (Shanker et al., 2005).

Chromium $(\mathrm{Cr})$ is widely distributed in nature, being the seventh most abundant metal in the Earth's crust (Panda and Choudhury, 2005). It occurs in several oxidation states, ranging from $\mathrm{Cr}(\mathrm{III})$ to $\mathrm{Cr}(\mathrm{VI})$, trivalent (III) and hexavalent (VI) chromium being the most stable and common states in the environment (Chandra and Kulshreshtha, 2004). $\mathrm{Cr}(\mathrm{VI})$ is considered the most toxic form of chromium, usually associated with oxygen as chromate $\left(\mathrm{CrO}_{4}^{2-}\right)$ or dichromate $\left(\mathrm{Cr}_{2} \mathrm{O}_{7}{ }^{2-}\right)$ oxyanions (Shanker et al., 2005). Due to their negative charge, both chromate and dichromate are rarely adsorbed by organic particles, being highly soluble in water. $\mathrm{Cr}$ (III) has lower mobility and toxicity and is found binding to organic matter in soil and aquatic environments (Becquer et al., 2003).

Contamination of soil and water due to the use of $\mathrm{Cr}(\mathrm{VI})$ in industrial activities has become a serious concern over the past two decades. Nriagu and Pacyna (1988) estimated that around 480 to 1,300 thousand tons of chromium are being added to soil each year, resulting mainly from the metallurgical and leather industry, fossil fuel combustion, and sewage sludge. The impact of this widespread contamination poses significant ecological risks (Roos, 1995), since Cr is considered to be a mutagenic, carcinogenic and teratogenic agent (Mitteregger-Junior et al., 2006). The biotoxicity of $\mathrm{Cr}(\mathrm{VI})$ is related to its ability to cross biological membranes, its strong oxidising capacity and its interference with the processes of respiration and photosynthesis (Shanker et al., 2005).

Chromium is found in all phases of the environment, including air, water and soil (Shanker et al., 2005). In Brazil, soil chromium content, found naturally in different types of soil, ranges from 9.6 to 75 mg.kg-1 (Fadigas et al., 2002). According to the Brazilian National Environmental Council (CONAMA), the current regulatory limit for $\mathrm{Cr}$ in water is 0.05 mg. $\mathrm{L}^{-1}$ (MMA, 1986).

Although chromium is not known to play any direct role in metabolic process, it is absorbed by plants, being detrimental to their growth and development (Shanker et al., 2005). The phytotoxicity of Cr generates an oxidative stress that leads to peroxidation of lipids. Consequently, severe damage to cell membranes and degradation of photosynthetic pigments and enzymes result in inhibition of germination and decreased plant growth (Poschenrieder et al., 1991; Panda and Choudhury, 2005), which may have a negative impact on the establishment of sensitive species.

Regnellidium diphyllum Lindman is a heterosporous fern of the family Marsileaceae. As to its natural distribution, $R$. diphyllum is limited to Southern Brazil and some adjoining localities in Uruguay and Argentina (Schultz,
1949; Alonso-Paz and Bassagoda, 2002). It grows in shallow waters or surrounding mud areas subjected to periodic flooding. In water, rhizomes grow attached to the mud and leaf laminae develop above the water surface. In Rio Grande do Sul, Brazil's southernmost state, it occurs mainly in the southern, southeastern and central-western lowlands of the state. This species has been assigned a vulnerable status on the list of endangered species in the state of Rio Grande do Sul, Brazil (SEMA, 2010).

As to its occurrence in the Sinos River Watershed, southern Brazil, there are records from 1935 and a single record from 2000. Voucher specimens are deposited at the Herbarium Anchieta (PACA), Universidade do Vale do Rio dos Sinos (PACA 2574, PACA 75252, PACA 89142) and at the Herbarium ICN, Instituto de Biociências, Universidade Federal do Rio Grande do Sul (ICN 15211). Sampling efforts conducted in recent years revealed several populations in other watersheds, but not in the Sinos River Watershed. It is worth noting that the Sinos River Watershed was also the habitat of another representative of the Marsileaceae, Pilularia americana A. Braun, which is currently considered to be extinct in the state (SEMA, 2010), being known all over Brazil based on this single collection (Esteio, leg. A. Schultz, 1955, ICN 1224). Several attempts to recollect this species in its original habitat were unsuccessful, and alterations in habitat conditions may have well accounted for its disappearance.

Considering that natural environments are exposed to intense and continuous alterations and pollution due to human activities and that little is known about the sensitivity of Regnellidium diphyllum to contaminants (Wunder et al., 2009; Cassanego et al., 2010), megaspore germination and initial development of sporophytes in the presence of chromium were investigated in vitro in order to establish the species' tolerance limits to this contaminant, as well as to evaluate biological responses during the initial stages of the life cycle.

\section{Material and Methods}

Mature sporocarps of Regnellidium diphyllum were obtained from different plants in the municipality of Viamão (30 05' 00' S and 50 47' 00" W, Rio Grande do Sul State, Brazil) and kept at room temperature (about $25^{\circ} \mathrm{C}$ ). Voucher specimens were deposited at the Herbarium Anchieta (PACA) at Universidade do Vale do Rio dos Sinos, São Leopoldo, Brazil.

After washing in tap water, sporocarps were rinsed in $70 \%$ ethanol solution, kept for 10 minutes in $7 \%$ sodium hypochlorite solution, then washed in sterile distilled water and dried on sterile filter paper at room temperature. Sporocarps were mechanically cracked to liberate the spores. Megaspores were manually isolated from microspores under a stereomicroscope. Megaspores from sporocarps of different plants were mixed to compose the sample. Taking into account the common occurrence of apogamy in megagametophytes of Regnellidium diphyllum (Mahlberg and Baldwin, 1975), only megaspores were used in order 
to obtain uniform cultures, thus avoiding the mixture of sexually and apomictically formed sporophytes.

As culture medium, Meyer's solution (Meyer et al., 1955) was prepared at different concentrations of $\mathrm{Cr}(\mathrm{VI})$ in the form of potassium dichromate $\left(\mathrm{K}_{2} \mathrm{Cr}_{2} \mathrm{O}_{7}\right)$. The $\mathrm{pH}$ was adjusted with $\mathrm{NaOH}$ to 6.0 before autoclaving and $\mathrm{K}_{2} \mathrm{Cr}_{2} \mathrm{O}_{7}$ was added to the medium after autoclaving. Two experiments were conducted to evaluate megaspore germination and sporophyte formation. In Experiment I, megaspores germination was evaluated at 0 (control), 0.1 , $0.5,1,5,10,15,20,30$, and $50 \mathrm{mg} \cdot \mathrm{L}^{-1} \mathrm{~K}_{2} \mathrm{Cr}_{2} \mathrm{O}_{7}$. Twenty-five megaspores were placed in each glass vial $(4.5 \times 10 \mathrm{~cm})$ with $25 \mathrm{~mL}$ of the solution, with four repetitions for each treatment. In Experiment II, sporophytic development was evaluated at 0 (control), 0.025, 0.05, 0.1, 0.2, 0.4, 0.8, 1.6, 3.2 , and $4.8 \mathrm{mg} . \mathrm{L}^{-1} \mathrm{~K}_{2} \mathrm{Cr}_{2} \mathrm{O}_{7}$. Fifteen megaspores were placed in each glass vial with $20 \mathrm{~mL}$ of the solution, with five repetitions for each treatment. The culture vials for both experiments were maintained in a growth chamber at $24 \pm 1{ }^{\circ} \mathrm{C}$, under artificial light with nominal irradiance of $77 \mu \mathrm{mol} . \mathrm{m}^{-2} / \mathrm{s}$ and a 12 -hour photoperiod.

In Experiment I, observations were made once a week for a total of 21 days. Every seven days, three germinated individuals were taken from each repetition. Megaspores showing at least one globular green structure with a crown of rhizoids were considered germinated. After 21 days, total percentage germination was calculated for each treatment.

In Experiment II, 10 individuals were eliminated from each glass vial at the end of seven days, thus maintaining five individuals in each repetition. The length of the primary root and the length of the primary and secondary leaves were measured for each individual after seven and 28 days in a laminar flow chamber.

Data on megaspore germination and sporophyte formation were then converted into percentages. Data were tested for normality and homogeneity using the Kolmogorov-Smirnov test and Levene's test, and ANOVA was applied to the data meeting the normality and homogeneity assumption. Differences between means were verified using Tukey's test, with $\alpha=0.05$. The Kruskal-Wallis test was applied to data that did not conform to normal distribution, and differences between means were verified using Dunn's test, with $\alpha=0.05$ (Zar, 1999). The analyses were conducted using the SPSS 12.0 software.

\section{Results}

The different $\mathrm{Cr}(\mathrm{VI})$ concentrations tested in Experiment I adversely affected megaspore germination. Germinated megaspores were classified in two types; those showing sporophytic structures and those without any further development. $\mathrm{Cr}(\mathrm{VI})$ concentration interfered with the capacity to develop sporophytes. From $10 \mathrm{mg} . \mathrm{L}^{-1}$ onwards, the percentage of germinated megaspores that did not form sporophytes was higher than the percentage obtained for megaspores exposed to lower $\mathrm{Cr}(\mathrm{VI})$ concentrations (Figure 1a). A significant negative influence was observed in sporophyte formation in the treatments from $0.5 \mathrm{mg} . \mathrm{L}^{-1}$ $\mathrm{Cr}(\mathrm{VI})$ concentration onwards (Figure $1 \mathrm{~b}$ ). Only the lowest $\mathrm{Cr}$ (VI) concentration tested $\left(0.05 \mathrm{mg} . \mathrm{L}^{-1}\right)$ did not differ significantly from the control. From 10 mg.L ${ }^{-1} \mathrm{Cr}(\mathrm{VI})$ concentration onwards, only 6 to $0 \%$ of the gametophytes formed sporophytes.

The length of the primary root of sporophytes was affected negatively by $\mathrm{Cr}(\mathrm{VI})$ after seven and 28 days in culture (Table 1). The development of primary and secondary leaves were also negatively affected by the presence of $\mathrm{Cr}(\mathrm{VI})$ in both recorded times. In treatments at 3.2 and $4.8 \mathrm{mg} . \mathrm{L}^{-1} \mathrm{Cr}$ (VI) concentrations, the secondary leaf was not formed after seven days in culture. After 28 days, small and morphologically anomalous leaves could be observed only in a reduced number of individuals at $4.8 \mathrm{mg} . \mathrm{L}^{-1}$ $\mathrm{Cr}(\mathrm{VI})$ concentration (Table 1). Plantlets exposed during 28 days to 3.2 and $4.8 \mathrm{mg} . \mathrm{L}^{-1} \mathrm{Cr}(\mathrm{VI})$ concentrations showed visible symptoms of leaf chlorosis and necrosis, as well as necrotic areas in the roots.

\section{Discussion}

Chromium is considered to be toxic to plants and does not play any role in plant metabolism (Dixit et al., 2002). Germination is the first physiological process affected by $\mathrm{Cr}(\mathrm{VI})$. Hydrolysis of proteins and starch provides amino acids and sugars essential for germination. $\mathrm{Cr}$ can decrease the production of $\alpha$ - and $\beta$-amylase, inhibiting germination and reducing the sugar content necessary for the development of embryo axes. On the other hand,
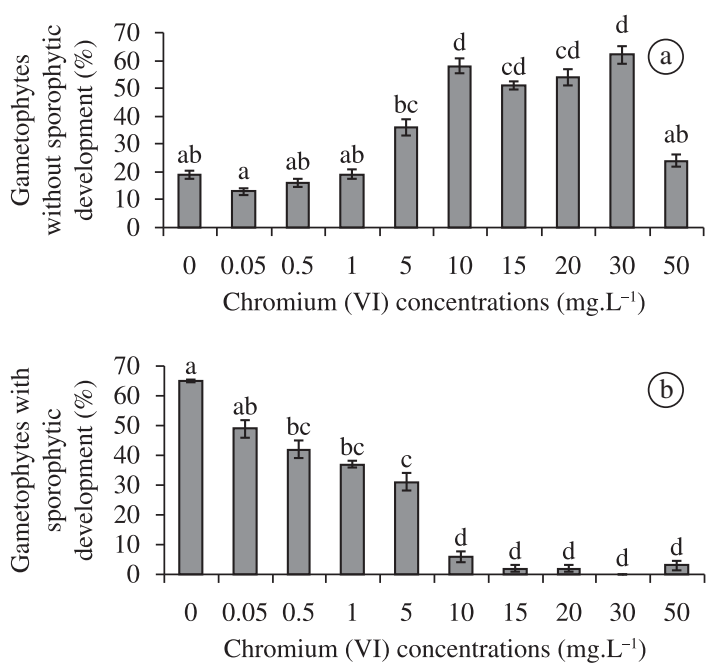

Figure 1. Germination of Regnellidium diphyllum Lindman megaspores at different Chromium(VI) concentrations after three weeks in culture (ANOVA, F $=7.75$, d.f. $=6,35$, $\mathrm{p}=0.001)$. ( $\mathrm{F}=$ value of the Snedecor distribution; d.f. $=$ degrees of freedom; $p$ = probability); a) Gametophytes without sporophytic development (\%); and b) Gametophytes with sporophytic development $(\%)$. Means with different letters are significantly different (Tukey's test, $\alpha=0.05$ ). Vertical bars indicate standard deviations. 
Table 1. Influence of different Chromium(VI) concentrations on the growth of Regnellidium diphyllum Lindman. Mean length of primary root and primary and secondary leaves after 7 and 28 days in culture (mean \pm standard deviation). Means with different letters in the same column are significantly different by Dunn's test $(\mathrm{P}=$ probability; $\mathrm{H}=$ statistics of the Kruskal-Wallis test; d.f. $=$ degrees of freedom).

\begin{tabular}{|c|c|c|c|c|c|c|}
\hline \multirow{2}{*}{$\begin{array}{c}\text { Chromium } \\
\left(\mathrm{mg}^{\left.-\mathrm{L}^{-1}\right)}\right.\end{array}$} & \multicolumn{2}{|c|}{ Primary root $(\mathbf{m m})$} & \multicolumn{2}{|c|}{ Primary leaf (mm) } & \multicolumn{2}{|c|}{ Secondary leaf (mm) } \\
\hline & 7 days & 28 days & 7 days & 28 days & 7 days & 28 days \\
\hline 0.0 & $5.72 \pm 1.30^{\mathrm{a}}$ & $6.80 \pm 0.72^{\mathrm{a}}$ & $8.00 \pm 0.86^{\mathrm{a}}$ & $10.12 \pm 0.50^{\mathrm{a}}$ & $0.86 \pm 0.43^{\mathrm{a}}$ & $9.04 \pm 0.75^{\mathrm{a}}$ \\
\hline 0.025 & $5.04 \pm 1.17^{\mathrm{a}}$ & $6.10 \pm 2.69^{\mathrm{ab}}$ & $8.36 \pm 1.66^{\mathrm{a}}$ & $6.42 \pm 2.20^{\mathrm{ab}}$ & $0.54 \pm 0.34^{\mathrm{a}}$ & $9.20 \pm 0.65^{\mathrm{a}}$ \\
\hline 0.05 & $2.02 \pm 0.67^{\mathrm{cd}}$ & $2.46 \pm 0.40^{\text {cde }}$ & $4.32 \pm 0.44^{\mathrm{b}}$ & $4.84 \pm 1.45^{\mathrm{bc}}$ & $0.12 \pm 0.22^{\mathrm{a}}$ & $6.04 \pm 0.93^{\mathrm{ab}}$ \\
\hline 0.1 & $4.24 \pm 1.20^{\mathrm{abc}}$ & $5.10 \pm 1.11^{\mathrm{abc}}$ & $7.60 \pm 1.46^{\mathrm{a}}$ & $6.60 \pm 2.66^{\mathrm{ab}}$ & $0.08 \pm 0.13^{\mathrm{a}}$ & $8.80 \pm 2.35^{\mathrm{a}}$ \\
\hline 0.2 & $2.06 \pm 0.77^{\mathrm{cd}}$ & $2.48 \pm 1.23^{\mathrm{cde}}$ & $4.82 \pm 2.02^{\mathrm{b}}$ & $4.40 \pm 2.98^{b c d}$ & $0.16 \pm 0.22^{\mathrm{a}}$ & $6.28 \pm 1.28^{\mathrm{ab}}$ \\
\hline 0.4 & $2.49 \pm 1.40^{\text {bcd }}$ & $3.14 \pm 1.53^{\text {cde }}$ & $8.72 \pm 0.44^{\mathrm{a}}$ & $8.16 \pm 0.97^{\mathrm{ab}}$ & $0.83 \pm 0.63^{\mathrm{a}}$ & $7.00 \pm 1.05^{\mathrm{a}}$ \\
\hline 0.8 & $4.86 \pm 1.47^{\mathrm{ab}}$ & $5.46 \pm 1.16^{\mathrm{abc}}$ & $8.72 \pm 0.44^{\mathrm{a}}$ & $10.40 \pm 0.60^{\mathrm{a}}$ & $0.85 \pm 0.54^{\mathrm{a}}$ & $9.00 \pm 1.24^{\mathrm{a}}$ \\
\hline 1.6 & $3.96 \pm 2.12^{\mathrm{abc}}$ & $3.72 \pm 3.00^{\mathrm{bcd}}$ & $8.18 \pm 1.68^{\mathrm{a}}$ & $8.40 \pm 3.57^{\mathrm{ab}}$ & $0.80 \pm 0.76^{\mathrm{a}}$ & $8.64 \pm 3.38^{\mathrm{a}}$ \\
\hline 3.2 & $0.15 \pm 0.16^{\mathrm{d}}$ & $0.0^{\mathrm{e}}$ & $0.62 \pm 0.84^{c}$ & $0.0^{\mathrm{d}}$ & $0.0^{\mathrm{b}}$ & $0.0^{\mathrm{d}}$ \\
\hline 4.8 & $0.38 \pm 0.55^{\mathrm{d}}$ & $0.56 \pm 0.78^{\mathrm{d}}$ & $1.18 \pm 1.81^{\mathrm{c}}$ & $1.64 \pm 2.48^{\mathrm{cd}}$ & $0.0^{\mathrm{b}}$ & $2.48 \pm 4.08^{\mathrm{cd}}$ \\
\hline & $\begin{array}{c}H=37.752 \\
\text { d.f. }=9,24 \\
p<0.001\end{array}$ & $\begin{array}{c}H=37.016 \\
\text { d.f. }=9,24 \\
p<0.001\end{array}$ & $\begin{array}{c}H=36.703 \\
\text { d.f. }=9,24 \\
p<0.001\end{array}$ & $\begin{array}{c}\mathrm{H}=36.571 \\
\text { d.f. }=9,24 \\
\mathrm{p}<0.001\end{array}$ & $\begin{array}{c}\mathrm{H}=31.89 \\
\text { d.f. }=9,24 \\
\mathrm{p}<0.001\end{array}$ & $\begin{array}{c}H=30.838 \\
\text { d.f. }=9,24 \\
p<0.001\end{array}$ \\
\hline
\end{tabular}

protease activity can be enhanced by the presence of $\mathrm{Cr}$, which also inhibits germination (Zeid, 2001).

The growth reduction of sporophytic structures, such as primary root, primary leaf and first secondary leaf, reported in this study for Regnellidium diphyllum was also verified in other species of aquatic macrophytes. For Myriophyllum spicatum L., maximum growth was obtained at $\mathrm{Cr}(\mathrm{VI})$ concentrations up to $50 \mu \mathrm{g} . \mathrm{L}^{-1}$ and concentrations higher than $1 \mathrm{mg} . \mathrm{L}^{-1}$ caused a linear reduction in plant weight and length (Guillizzoni et al., 1984).

Nichols et al. (2000) verified a significant growth reduction in the fern Salvinia minima Baker cultivated in vitro with Hoagland solution at $\mathrm{Cr}(\mathrm{IV})$ concentrations of $1 \mathrm{mg} . \mathrm{L}^{-1}$ and higher. $\mathrm{Cr}(\mathrm{VI})$ was shown to have a cumulative effect on the fern, and growth reduction could be related to a decreased nutrient uptake. Sela et al. (1989) showed that the presence of $\mathrm{Cr}(\mathrm{VI})$ can lead to a decrease in $\mathrm{Ca}$, $\mathrm{Mg}$ and $\mathrm{K}$ uptake. Similar influence of $\mathrm{Cr}$ on the uptake of mineral nutrients was reported for $\mathrm{P}, \mathrm{Na}, \mathrm{N}, \mathrm{Fe}$, and $\mathrm{Cu}$ (Moral et al., 1995, 1996).

In the present study, white and brown leaves, as well as root browning, could be observed in sporophytes exposed to $0.2 \mathrm{mg} . \mathrm{L}^{-1} \mathrm{Cr}(\mathrm{VI})$ concentration and higher. Similar observations were made concerning the aquatic macrophyte Limnanthemum cristatum (Roxb.) Griseb. exposed to a $1 \mathrm{mg} . \mathrm{L}^{-1} \mathrm{Cr}$ concentration, which showed reduced length and lack of colour or brown colour of roots, in addition to significant morphological changes (Garg et al., 1994).

Symptoms of chlorosis in young leaves and the associated reduction in chlorophyll content can be attributed to $\mathrm{Cr}$ accumulation in plants (McGrath, 1985; Panda and Patra, 1997; Panda and Dash, 1999; Nichols et al., 2000; Panda, 2003; Panda et al., 2003). Ultrastructural modifications in chloroplasts with significant reduction in chlorophyll- $a$, chlorophyll- $b$ and carotenoid concentrations are related to growth inhibition and could be observed in plants such as Lemna minor L., Pistia stratiotes L. (Bassi et al., 1990), and Taxithelium nepalense (Schwägr.) Broth. (Panda and Choudhury, 2005).

Considering the negative impact of $\mathrm{Cr}(\mathrm{VI})$ on megaspore germination and initial sporophytic development of Regnellidium diphyllum even at low concentrations, the contamination of aquatic environments by industrial effluents could be regarded as a threat to the establishment and preservation of populations of the currently vulnerable R. diphyllum.

Acknowledgements - The authors are grateful to the Universidade do Vale do Rio dos Sinos for the use of laboratories and for the scholarship granted to the first author; to the Universidade Feevale, to the Universidade Federal do Rio Grande do Sul (UFRGS), and to the Conselho Nacional de Desenvolvimento Científico e Tecnológico (CNPq) for the support and research grants.

\section{References}

ALONSO-PAZ, E. and BASSAGODA, MJ., 2002. Revisión de las Marsileaceae del Uruguay y primera cita de Pilularia americana A. Braun. Comunicaciones Botânicas - Museo Nacional de Historia Natural y Antropologia, vol. 125, no. 6, p. 18.

BASSI, M., CORRADI, MG. and FAVALI, MA., 1990. Effect of chromium (VI) on two fresh water plants, Lemna minor and Pistia stratiotes: II. Biochemical and physiological observations. Cytobios, vol. 62, p. 101-109.

BECQUER, T., QUANTIN, C., SICOT, M. and BOUDOT, JP., 2003. Chromium availability in ultramafic soils from New Caledonia. Science of the Total Environment, vol. 301, p. 251-261.

CASSANEGO, MBB., DROSTE, A. and WINDISCH, PG., 2010. Effects of 2,4-D on the germination of megaspores and initial 
development of Regnellidium diphyllum Lindman (Monilophyta, Marsileaceae). Brazilian Journal of Biology, vol. 70, no. 2, p. 361-366.

CHANDRA, P. and KULSHRESHTHA, K., 2004. Chromium accumulation and toxicity in aquatic vascular plants. The Botanical Review, vol. 70, no. 3, p. 313-327.

DIXIT, V., PANDEY, V. and SHYAM, R., 2002. Chromium ions inactivate electron transport and enhance superoxide generation in vivo in pea (Pisum sativum L. cv: Azad) root mitochondria. Plant Cell \& Environment, vol. 25, p. 687-693.

FADIGAS, FS., AMARAL-SOBRINHO, NMB., MAZUR, N., ANJOS, LHC. and FREIXO, AA., 2002. Concentrações naturais de metais pesados em algumas classes de solos brasileiros. Bragantia, vol. 61, no. 2, p. 151-159.

GARG, P., CHANDRA, P. and DEVI, S., 1994. Chromium(VI) induced morphological changes in Limnanthemum cristatum Griseb.: A possible bioindicator. Phytomorphology, vol. 44, no. 3-4, p. 201-206.

GUILLIZZONI, P., ADAMS, MS. and MCGAFFEY, N., 1984. The effect of chromium on growth and photosynthesis of a submerged macrophyte, Miriophyllum spicatum. In RASMUSSEN. Ecotoxicology: Proceedings of the third Oikos Conference. Stockholm: Ecological Bulletins, p. 90-96.

MAHLBERG, PG. and BALDWIN, M., 1975. Experimental studies on megaspore viability, parthenogenesis and sporophyte formation in Marsilea, Pilularia and Regnellidium. Botanical Gazette, vol. 136, no. 3, p. 269-273.

McGRATH, SP., 1985. Chromium and nickel. In ALLOWAY, BJ. Heavy metals in soil. London: Chapman and Hall, p. 139-167.

MEYER, BS., ANDERSON, DB. and SWANSON, CA., 1955. Laboratory plant physiology. Princeton: Van Nostrand, 168 p.

Ministério do Meio Ambiente - MMA, 1986. Resolução CONAMA no. 20, de 18 de junho de 1986. Dispõe sobre a classificação das águas e estabelece os limites máximos das substâncias potencialmente prejudiciais. Diário Oficial da União, Poder Executivo, Brasília, DF, 30 jul. 1986. Seção II, p. 8.

MITTEREGGER-JUNIOR, H., FERRAZ-DIAS, J., LÚCIAYONEMA, M., ARENZON, A. and PEGAS-HENRIQUES, JA., 2006. Avaliação das atividades tóxicas e mutagênicas da água e do sedimento do arroio Estância Velha, região coureirocalçadista, utilizando Allium cepa. Journal of the Brazilian Society of Ecotoxicology, vol. 2, no. 1, p. 147-151.

MORAL, R., GOMEZ, I., PEDRENO, JN. and MATAIX, J., 1996. Absorption of $\mathrm{Cr}$ and effects on micronutrient content in tomato plant (Lycopersicum esculentum M). Agrochimica, vol. 40 , p. 132-138.

MORAL, R., PEDRENO, JN., GOMEZ, I. and MATAIX, J., 1995. Effects of chromium on the nutrient element content and morphology of tomato. Journal of Plant Nutrition, vol. 18, p. $815-822$.
NICHOLS, PB., COUCH, JD. and AL-HAMDANI, SH., 2000. Selected physiological responses of Salvinia minima to different chromium concentrations. Aquatic Botany, vol. 68, p. 313-319.

NRIAGU, JO. and PACYNA, JM., 1988. Quantitative assessment of worldwide contamination of air, waters and soils with trace metal. Nature, vol. 333, p. 134-139.

PANDA, SK. and CHOUDHURY, S., 2005. Chromium stress in plants. Brazilian Journal of Plant Physiology, vol. 17, no. 1, p. $95-102$.

PANDA, SK. and DASH, M., 1999. Regulation of senescence by $\mathrm{Cr}(\mathrm{VI})$ ions in excide wheat leaves. Journal of the Nature and Botanical Society, vol. 53, p. 35-37.

PANDA, SK. and PATRA, HK., 1997. Physiology of chromium toxicity in plants - A review. Plant Physiology and Biochemistry, vol. 24 , no. 1 , p. 10-17.

PANDA, SK., 2003. Heavy metal phytotoxicity induced oxidative stress in Taxithelium sp. Current Science, vol. 84, p. 631-633.

PANDA, SK., CHOUDHURY, I. and KHAN, MH., 2003. Heavy metals induce lipid peroxidation and affects antioxidants in wheat leaves. Biologia Plantarum, vol. 46, p. 289-294.

POSCHENRIEDER, C., VAZQUEZ, MD., BONET, A. and BARCELO, J., 1991. Chromium III iron interaction in iron sufficient and iron deficient bean plants. II ultrastructural aspects. Journal of Plant Nutrition, vol. 14, p. 415-428.

ROOS, MC., 1995. Charting tropical plant diversity: Europe's contribution and potential. Working document European Science Foundation/Linnean Society/Rijksherbarium Hortus Botanicus/ Systematics Association workshop "Systematics Agenda 2000: the challenge for Europe", Leiden.

SCHULTZ, AR., 1949. Contribuições ao conhecimento de Regnellidium diphyllum Lindman. Lilloa, vol. 17, p. 139-144.

Secretaria do Meio Ambiente - SEMA. Espécies da flora ameaçadas de extinção do Rio Grande do Sul. Porto Alegre: Secretaria do Meio Ambiente. Available from: <http://www.sema.rs.gov.br/sema/ html/pdf/especies-ameacadas.pdf $>$. Access in: 05 jan. 2010.

SELA, M., GARTY, J. and TEL-OR, E., 1989. The accumulation and the effect of heavy metals on the water fern, Azolla filiculoides. New Phytologist, vol. 112, p. 7-12.

SHANKER, AK., CERVANTES, C., LOZA-TAVERA, H. and AVUDAINAYAGAM, S., 2005. Chromium toxicity in plants. Environment International, vol. 31, p. 739-753.

WUNDER, DA., DROSTE, A. and WINDISCH, PG., 2009. Megaspore germination and initial development of Regnellidium diphyllum Lindman (Pteridophyta, Marsileaceae) sporophytes in the presence of cadmium. Revista Brasileira de Botânica, v. 31, p. 177-181.

ZAR, JH., 1999. Biostatistical analyses. $4^{\text {th }}$ ed. Upper Saddle River: Prentice-Hall, 931 p.

ZEID, IM., 2001. Responses of Phaseolus vulgaris to chromium and cobalt treatment. Biologia Plantarum, vol. 44, p. 111-115. 